\title{
LA DEVOCIÓN A LAS ÁNIMAS DEL PURGATORIO EN CÁDIZ: DOS HERMANDADES PARA SU ESTUDIO
}

\author{
RAQUEL SIGÜENZA MARTíN \\ UNIVERSIDAD DE COMPLUTENSE DE MADRID \\ José MARÍa Collantes GonZÁlez \\ UNIVERSIDAD NACIONAL A DisTANCIA
}

\begin{abstract}
RESUMEN: A partir de los ataques de Lutero contra la idea del purgatorio, España mantuvo con intensidad la defensa de su existencia con multitud de tratados y expresiones cultuales. Cádiz no fue una excepción en el desarrollo del culto a las ánimas del purgatorio, con diferentes hermandades nacidas para mantenerlo. Entre todas ellas destacan las elegidas para este artículo: la Esclavitud del Santísimo Sacramento y archicofradía de las Benditas Ánimas, y la Hermandad de San Nicolás de Tolentino localizada en el convento de San Agustín, cuyo estudio se acomete a continuación.
\end{abstract}

PALABRAS CLAVE: purgatorio; ánimas; hermandades; Cádiz.

\section{DEVOTION TO THE SOULS IN PURGATORY IN CÁDIZ: A STUDY OF TWO BROTHERHOODS}

\begin{abstract}
Since the attack by Martin Luther against the idea of Purgatory, Spain maintained a passionate defence of its existence through several treatises and manifestations of its cult. Cádiz was not an exception in the development of the devotion to the souls in Purgatory and different brotherhoods were founded in order to keep this idea alive. In this article, we have chosen to study the two brotherhoods which stand out amongst them all: the Slavery of the Holy Sacrament and the Confraternity of the Blessed Souls and the Brotherhood of St. Nicholas of Tolentino in the San Agustin convent.
\end{abstract}

KEY WORDS: Purgatory; souls; brotherhoods; Cádiz.

Recibido: 13-03-2014/Aceptado: 04-05-2014 


\section{LAS ÁNIMAS DEL PURGATORIO}

Mucho se ha escrito acerca del purgatorio, de las ánimas que allí se encuentran penando de manera transitoria por ciertos pecados cometidos durante su vida, del tipo de faltas que las llevó hasta allí y del modo en el que los vivos podían aliviar o acortar su estancia en aquel lugar.

La preocupación por la muerte, especialmente cuando la esperanza de vida, por motivos diversos, no era tan alta como en la actualidad, ha sido una constante en la sociedad en general, y en la católica en particular. Los primeros pensamientos dedicados a la situación de las almas desde el fallecimiento de la persona hasta la llegada del Juicio Final se dieron entre los siglos II y IV. Fue entonces cuando se empezó a plantear la posibilidad de que, además de las almas condenadas que iban al infierno y las salvadas, que se dirigían al cielo, existiera también un tipo de pecadores cuyas almas podrían salvarse después de superar ciertas pruebas. Así, la idea del purgatorio como lugar intermedio donde se mantuvieran dichas ánimas realizando las aludidas pruebas hasta su definitiva liberación, no surgió hasta el XII y estuvo íntimamente ligada a la consideración de un tipo de pecados, de carácter menos grave y denominados veniales, que no permitían la salvación inmediata pero tampoco podían condenar eternamente a quienes los habían cometido ${ }^{1}$.

Es cierto que, desde antiguo, se ha creído que los muertos pueden de algún modo ayudar a los que están vivos, pero también estos tenían que llevar a cabo algunas acciones para beneficio de los ya ausentes, y este argumento se ha esgrimido con frecuencia para responder a por qué era necesario ofrecer ciertos sufragios por las almas de los difuntos que, una vez salvadas, rezarían por las nuestras. En ese sentido, no hace falta recordar las ofrendas que muchos pueblos de la antigüedad dedicaban a sus muertos. Y todavía en el siglo XIX, fray José Coll incluía en su obra El purgatorio y la devoción a las ánimas benditas ${ }^{2}$, múltiples ejemplos tomados de las Sagradas Escrituras que interpretaba como evidencia de que las almas de los fallecidos necesitaban algún tipo de socorro prestado por los vivos.

Asunto muy discutido fue, igualmente, el tipo de penas que tenían lugar en el purgatorio. Tanto las protagonizadas por el hielo como -y sobre todo- aquellas relacionadas con el fuego, fueron las más repetidas entre quienes se dedicaron a teorizar sobre este asunto. En los relatos de apariciones ante los vivos y viajes de estos al purgatorio, las llamas tuvieron siempre una constante presencia, aunque, a diferencia de las del infierno, que

\footnotetext{
${ }^{1}$ LE GOFF, Jacques, El nacimiento del purgatorio, Madrid, Taurus, 1981, pp. 11 y 15.

${ }^{2}$ COLL, Fray José, El purgatorio y la devoción a las ánimas benditas, Madrid, Imprenta de F. Maroto e hijos, 18812, pp. 17-23.
} 
castigan, las del tercer lugar, como denominó Lutero al purgatorio, purifican. A esto se le unía la privación de la visión divina, hecho que, en sí mismo, se consideraba un suplicio.

De esta manera, la Iglesia incidió en la necesidad de realizar determinados sufragios a favor de los difuntos y que, desde san Agustín y san Gregorio Magno, se establecieron en: misas -el tipo de ayuda más importante-, oraciones, limosnas y obras piadosas como el ayuno y la abstinencia ${ }^{3}$. Además, existía la llamada demanda o "limosna y bacín", necesaria para poder hacer frente a los gastos derivados de las misas y que se llevaba a cabo en el ofertorio, después del credo, y solía recogerse por orden de importancia social de los asistentes, como en otros ritos. El encargado de portar la bacineta o cepillo limosnero se llamaba bacinador (término hoy en desuso según el Diccionario de la Real Academia de la Lengua), o bacinero.

Por otro lado, para reparar el agravio que implicaba haber cometido un pecado, existía la posibilidad de obtener dos tipos de indulgencias, las plenarias, que perdonaban todas las faltas, y las parciales, que reducían los días de penitencia. Y esto se aplicaba también a las ánimas del purgatorio, que, en España, se beneficiaban principalmente de las bulas de difuntos y de aquellas otras que en principio se habían destinado a quienes iban a luchar a Tierra Santa, motivo por el cual se conocieron como bulas de la Santa Cruzada.

$\mathrm{El}$ ataque de Lutero al comercio surgido alrededor de la venta de indulgencias y al purgatorio $^{6}$-lugar inventado, pues no aparece en las Escrituras-, tuvo como respuesta una fuerte defensa del mismo por parte de la Iglesia católica. En Trento (1545-1563) se reforzó la idea de que los sufrimientos de las ánimas podían aliviarse a través de diferentes tipos de socorros y el nacimiento de hermandades y cofradías, así como la proliferación de capillas al tener un gran cuadro con varias ánimas retorciéndose entre llamas se las llamó popularmente "capillas del infierno" multiplicó a partir del siglo XVI.

Mientras tanto, para el pueblo llano, el hecho de que la divinidad se encontrase demasiado alejada de su realidad cotidiana hizo que la Virgen y los santos tuvieran una

\footnotetext{
${ }^{3}$ LE GOFF, Jacques, op. cit., pp. 169-170; COLL, José, op. cit., p. 94.

4 TORRES JIMÉNEZ, Ma Raquel, Formas de organización y práctica religiosa en Castilla la Nueva, siglos XIII al XVI, (tesis doctoral), Madrid, Universidad Complutense, 2002, p. 2749.

5 TAUSIET, María, "Gritos del más allá. La defensa del purgatorio en España”, Hispania Sacra, 57 (2005), p. 97.

${ }^{6}$ En varias de sus noventa y cinco tesis, se presentaba contrario a la idea de que existiera un lugar de penitencia entre cielo e infierno, y esta crítica se agudiza en su Retractación del Purgatorio de 1530, llegando a considerarlo como una argucia del diablo en los artículos de Esmalcalda de 1537. Similar era la opinión de Calvino, para quien el purgatorio era una "fábula fatal de Satanás que destruye la virtud de la cruz de Cristo", eadem, p. 86 , n. 6 .

7 MATARÍN GUIL, Manuel Francisco, "Creencia popular en las ánimas del purgatorio en los valles de los ríos Andarax y Nacimiento (Almería)", Actas de las primeras jornadas de Religiosidad Popular, Almería, 1996, pp. 75-90.
} 
rápida acogida como mediadores entre el cielo y la tierra. En consecuencia, diferentes advocaciones marianas y ciertos santos que mantenían una especial relación con las almas de los muertos se convirtieron en los intercesores predilectos de la población, y así suele representarse artísticamente, como vamos a ver a continuación.

\section{LA DEVOCIÓN A LAS ÁNIMAS EN CÁDIZ}

España fue una ardiente defensora del purgatorio, con múltiples tratados teóricos nacidos a partir del siglo XVI que pretendían demostrar la certeza de su existencia y una gran diversidad de expresiones cultuales a las que fueron afectas todas las clases sociales. Cádiz no es ninguna excepción a la hora de mantener y desarrollar este culto a las ánimas: varias fueron las hermandades allí nacidas (Morgado defiende que, según el libro de subsidios de 1596-1623, en 1605 había una cofradía dedicada a las ánimas en toda la diócesis; pero según una visita pastoral de 1717, por entonces existían diecisiete cofradías o hermandades del Santísimo Sacramento o de las ánimas de un total de sesenta y siete localizadas en Vejer, Chiclana, Conil, Medina Sidonia, Alcalá, Jimena, Castellar y Tarifa, añadiendo, además, que fueron congregaciones mimadas por las altas esferas de la Iglesia y la sociedad, siendo las más difundidas. Años después, en 1799, el libro de subsidios de 1777-1802, registraba un total de diecinueve cofradías del Santísimo Sacramento y ánimas del purgatorio, que se encontraban distribuidas por todo el obispado salvo en Paterna y la Isla de León ${ }^{8}$; diversas son también las representaciones artísticas que aún hoy se conservan y, por supuesto, se dieron publicaciones, celebraciones y referencias testamentarias variadas relacionadas con esta devoción, así como los toques de ánimas que tañían las campanas cuando era menester.

De este modo, entre las referencias más antiguas que hemos localizado se encuentra la fundación, en 1559, de la esclavitud del Santísimo Sacramento y archicofradía de las benditas ánimas del purgatorio con sede en la catedral (hoy parroquia de Santa Cruz); más tarde, el 16 de abril de 1561, Juan Potin otorgaba testamento, pidiendo que sus restos descansaran en el altar de ánimas de Santa Cruz, lo que de nuevo pedía María de Medina en 1565, un año después de que Ana González hubiera dejado seis reales para la cofradía de

\footnotetext{
8 MORGADO GARCÍA, Arturo, La diócesis de Cádiz: de Trento a la Desamortización, Cádiz, Universidad de Cádiz, 2008, pp. 20 y 378, y Estamento eclesiástico y vida espiritual en la diócesis de Cádiz en el siglo XVII, Cádiz, Universidad de Cádiz, 1996, pp. 220-221. No obstante, Mósig Pérez afirma que la venerable esclavitud del Santísimo y archicofradía de las benditas ánimas de San Fernando (antigua Isla de León), fue fundada en 1733, obteniendo la aprobación civil en 1796, en: MÓSIG PÉREZ, Fernando, "Santísimo Sacramento y ánimas", en Arte e historia. Hermandades extinguidas [en línea]. Disponible en: http://www.islapasion.net/arteehistoria/hermandadesextinguidas_mosig5.html [Consulta: 12/06/13].
} 
las ánimas ${ }^{9}$; en cuanto a las publicaciones ${ }^{10}$, en 1638 veía la luz el Tesoro celestial y divino para rescate y consuelo de las almas: en que se trata de las mas principales indulgencias que ay (sic) en la Iglesia de Dios, del padre franciscano Lorenzo de San Francisco, que volvería a editarse en 1665; y en los años finales del XVII, la recopilación de sermones que el obispo gaditano José de Barcia y Zambrana había pronunciado entre 1671 y 1690 en Toledo, Madrid y Granada, se hacían públicos en diversas ediciones de su Despertador cristiano, santoral de varios sermones de santos, de aniversarios de ánimas y honras. Ya en el XVIII, el capuchino Feliciano de Sevilla daba a la imprenta en 1704 su Racional campana de fuego que toca a que acudan todos los fieles con agua de sufragios a mitigar el incendio del Purgatorio, en que se queman vivas las benditas Animas que allí penan y de 1794 data la reimpresión de El Purgatorio abierto a la piedad de los vivos: breve cotidiano ejercicio en sufragio de las almas del purgatorio, traducido del francés al italiano y de este idioma al español por Ventura de Goti.

En 1793, dos años después de que viera la luz en Madrid, se publicaba en Cádiz, por solicitud de un sacerdote gaditano devoto de las ánimas, el Voto de cesión total de las obras satisfactorias a favor de las almas de el Purgatorio (...) en su sermón predicado el día 29 de junio de 1790 de fray Martín de Barcelona. La existencia de este voto, por el cual quien lo pronunciaba se comprometía a redimir a través de sus propias obras de caridad aquellas almas del purgatorio que la Virgen escogiera, se remonta al 21 de noviembre de 1704, cuando el padre Gaspar Oliden lo confirmó formalmente en la iglesia de Santa María del Favor de Madrid. En 1726, después de predicarlo por España e Italia, logró hacerlo ante Benedicto XIII, que otorgó un breve favorable al mismo el 20 de mayo de aquel año. El 23 de agosto de 1728, el mencionado pontífice concedía las siguientes gracias a quienes hubiesen pronunciado el voto promulgado por el padre Oliden: si eran sacerdotes, se consideraba privilegiado cualquier altar en el que celebrasen misa, para que saliera del purgatorio el ánima elegida por la Virgen; y para los fieles en general, por un lado sacarían un ánima del purgatorio por cada misa oída en lunes y por las escuchadas en los días que, sin ser lunes, comulgasen y, por otro, podían aplicar todas las indulgencias concedidas a modo de sufragio para las benditas ánimas. En 1788, Pío VI confirmaba dichos privilegios y, llegando la noticia a los obispos y arzobispos de España y las Indias, muchos de ellos,

\footnotetext{
${ }^{9}$ ESPINOSA DE LOS MONTEROS SÁNCHEZ, Francisco, "La religiosidad popular gaditana a través de las disposiciones testamentarias del siglo XVI”, Trocadero, 17 (2005), p. 157.

10 Todas las publicaciones que se mencionan en los siguientes párrafos se pueden encontrar en el Catálogo Colectivo del Patrimonio Bibliográfico Español [en línea]. Disponible en: http://www.mcu.es/bibliotecas/MC/CCPB/index.html [Consulta: 15/07/2013]. Sobre el obispo José de Barcia, vid.: MORGADO GARCÍA, Arturo, op. cit., 2008, pp. 77 y 252.
} 
como el obispo de Cádiz, estuvieron a favor. Finalmente, Pío IX especificaba de nuevo estas indulgencias el 30 de septiembre de $1852^{11}$.

Pero las acciones de Benedicto XIII a favor de la doctrina del purgatorio habían comenzado con anterioridad, como lo refleja la losa localizada en el claustro del gaditano convento de Santo Domingo, en la que se hace referencia a la bula dada por este pontífice el 22 de septiembre de 1724 en Santa María la Mayor, por la que concedía la liberación de un ánima a los sacerdotes dominicos que celebraran misa en algún altar de su orden.

La continuación de textos de diversa índole dedicados a las almas del purgatorio en Cádiz llega hasta bien entrado el XIX, con obras como el Novenario sagrado por las Benditas Ánimas del Purgatorio: para el ejercicio de la piadosa confradía (sic) de la Resurrección del Señor y Animas benditas, publicado en 1857 o el Devoto quinario y piadoso ejercicio que a favor de las almas del purgatorio se practica en la iglesia de los descalzos de esta ciudad, del año siguiente.

En cuanto a los toques de campanas relacionados con las ánimas, sabemos que en el siglo XVIII y dentro de las catorce veces que diariamente se tañían las de la catedral gaditana en las diversas llamadas ordinarias para la población, el último que sonaba a las diez de la noche era precisamente el toque de ánimas, que se codificaba mediante tres golpes dados simultáneamente con las campanas tercera y cuarta y golpes alternados con una y otra durante un tiempo, para terminar como se había iniciado. Invitaba a la plegaria en privado y servía, al mismo tiempo, para señalar la hora a la que los comerciantes debían cerrar sus puertas al público. Además, todos los lunes al amanecer se repetía este mismo toque para anunciar la misa de Ánimas ${ }^{12}$.

Finalmente, respecto a las disposiciones testamentarias, Morgado García, tomando una muestra de las últimas voluntades de ciento veintiún clérigos procedentes de Alcalá de los Gazules, Medina Sidonia y Cádiz, todas ellas fechadas entre 1685 y 1699 , ofrece algunas interesantes conclusiones que atañen al asunto que nos ocupa, como que el 95 por ciento de los alcalaínos, el 97 por ciento de los asidonenses y el 73 por ciento de los gaditanos dispusieron la celebración tras su muerte de cientos de misas por la salvación de

11 PASCUA SÁNCHEZ, María José de la, Actitudes ante la muerte en el Cádiz de la primera mitad del siglo XVIII, Cádiz, Diputación Provincial, 1984, p. 81; BARCELONA, Martín de, Voto de cesión total de las obras satisfactorias a favor de las almas del purgatorio (...) En su Sermón Predicado el día 29 de Junio de 1790, Cádiz, Imprenta de la Ciudad, 1793, pp. 1-7 y 15-16; ROXAS, Manuel de, Breve instrucción de un Examinador sinodal de este arzobispado de Granada sobre el Voto Caritativo y Heroico (...) para favorecer (...) á las benditas Animas del purgatorio, Granada, Impr. Juan Esteban Alonso, 1827, pp. 3-6 y COLL, José, op. cit., pp. 116-119.

12 DÍEZ MARTÍNEZ, Marcelino, "El lenguaje de las campanas: un ingrediente de la vida diaria gaditana en el siglo XVIII”, Tavira, 16 (1999), p. 153. Según documento del obispo José Escalzo y Miguel fechado el 10 de agosto de 1789 y localizado en la Biblioteca de Temas Gaditanos en el que se intenta, siguiendo el ejemplo del arzobispo de Toledo, codificar el uso y toque de las campanas de los templos de la ciudad, exceptuando las de la catedral. Ofrece el prelado, para ello, un total de nueve reglas que eviten las molestias a los habitantes y regulen este asunto en las iglesias del lugar. 
su alma -mientras que en el caso de los testamentos de los capitulares, que analiza más adelante, estas misas están menos presentes-, siendo especialmente relevantes las palabras de Francisco González de Figueredo, de Medina Sidonia, quien especificaba que la celebración de las mismas debía hacerse "por mi alma, por mi intención por las penitencias mal cumplidas por las personas a quien puedo ser en algún cargo de que por particular no me acuerdo por las benditas ánimas del purgatorio y por las de mis padres... por las cuales pongo en manos de mi señor Jesucristo para que su Divina Majestad las divida y reparta según y como más convenga a su santo servicio y salvación de mi alma". Curioso es, además, el caso de Rafael de Sopranis Boquín, quien disponía en Cádiz la fundación de tres capellanías perpetuas, estando la primera destinada a las misas por su alma y la última de ellas "por el indio más necesitado que en todo tiempo estuviere en el Purgatorio para que salga a gozar de la gloria y después de ella por el alma o almas de dichos indios a quien su Divina Majestad fuere servido aplicarlas”"13.

Así pues, aunque la preocupación por las ánimas del purgatorio se extiende por toda la provincia, como acabamos de ver, es en la capital donde hemos centrado nuestra investigación.

En ella aparecen diferentes congregaciones así como representaciones de diversa índole que en un primer momento, durante su recopilación, pensamos organizar y analizar iconográfica y cronológicamente; sin embargo, las necesarias limitaciones de espacio para la elaboración de este texto nos ha llevado a centrar el estudio de manera exclusiva en dos congregaciones: la esclavitud del Santísimo Sacramento y archicofradía de las benditas ánimas y la hermandad de San Nicolás de Tolentino en la iglesia del convento de San Agustín, incluyendo además otras referencias localizadas en sus respectivas sedes, independientemente de su relación con las congregaciones.

\section{ESCLAVITUD DEL SANTÍSIMO SACRAMENTO Y ARCHICOFRADÍA DE LAS BENDITAS ÁNIMAS}

Ya se dijo que el nacimiento de esta asociación se remonta a 1559 y estaba localizada, originariamente, en la sede episcopal de aquel momento -hoy parroquia de Santa Cruz-, donde no queda rastro alguno de la misma, como hemos podido comprobar y se nos ha

13 MORGADO GARCÍA, Arturo, op. cit., 2008, pp. 303, 311, 316 y 320. El testamento de Francisco González de Figueredo en: Archivo Histórico Provincial de Cádiz (A.H.P.C.), Protocolos Medina, lib. 647, fols. 400v-401 y las disposiciones de Rafael de Sopranis Boquín en: A.H.P.C., Protocolos Cádiz, lib. 1438, fols. 105-106. 
corroborado personalmente. Su sede cambió a la parroquia de San Antonio, y allí se mantiene en la actualidad, aunque quedan elementos vinculados a la devoción que promovían en otros templos de la capital ${ }^{14}$.

La documentación más útil que hemos podido encontrar para entender el funcionamiento de esta hermandad y algunos detalles sobre la misma es el texto fechado en 1920 donde se recogen sus estatutos ${ }^{15}$. A pesar de las lagunas existentes hasta el momento sobre su evolución, en las próximas líneas exponemos todas las noticias que nos ha sido posible recopilar.

En primer lugar, queremos destacar que, al considerar el sacrificio de la misa como el más importante sufragio que los vivos podían ofrecer a favor de las almas penitentes, no resulta extraña esta unión entre dos corporaciones dedicadas a mantener y extender la devoción por el Santísimo Sacramento y las ánimas benditas, y precisamente los aludidos estatutos señalan que el principal objetivo de esta congregación, además de ofrecer el correspondiente culto al Santísimo, era recoger limosna para hacer frente al sufragio del mayor número posible de misas de ánimas que, por otra parte y debido a la creencia de que no siempre Dios admitía las ofrendas hechas y tal vez la que se omitía era precisamente la que el Señor estaba esperando, se multiplicaban en funerales, misas del día siguiente, de réquiem, memorias, capellanías perpetuas o aniversarios, etc. Pretendiendo ser la única corporación que pudiese recoger limosnas con este fin en toda la ciudad, en 1619 iniciaron un pleito al considerar que el ejercicio limosnero desempeñado por las órdenes de San Agustín y San Juan de Dios les provocaba un perjuicio económico y en 1734 se reiteraban las protestas porque otras hermandades se dedicaban al mismo menester para beneficio de las ánimas del purgatorio ${ }^{16}$.

Alonso de la Sierra especifica, por un lado, que las cuentas de la esclavitud y de la archicofradía se llevaron de manera independiente a pesar de que ambas congregaciones se han mantenido siempre unidas mientras que, por otro lado, habla de una cierta limitación de este culto porque hasta 1787 solo existió una parroquia, que era la catedral; no obstante,

\footnotetext{
${ }^{14}$ Somos conscientes de la necesidad de investigar en el archivo de la parroquia de San Antonio para el asunto que nos ocupa. Sin embargo el acceso al mismo es, hasta el momento, imposible. Lo mismo podemos decir del Archivo Diocesano de Cádiz (A.D.C.), donde se nos ha explicado que parte de la documentación ya no está allí y los legajos que precisábamos ver, no sólo para este apartado sino para la totalidad del presente estudio, no los localizaban.

15 Estatutos para el mejor régimen y dirección de la Venerable e Inmemorial Esclavitud del Santísimo Sacramento y Archicofradía de las Benditas Animas, Cádiz, Tipografía Ordóñez C. del Castillo, 1920.

16 Ibidem, p. 7; TAUSIET, María, op. cit., p. 98; MORGADO GARCÍA, Arturo, op. cit., 1996, pp. 218-219, 371 y 374 (las menciones sobre la actividad de la cofradía pidiendo limosna para el viático, en: A.D.C., Varios, leg. 1860, "Cofradía del Santísimo Sacramento y Ánimas del Purgatorio" (1619) y el pleito con agustinos y hermanos de San Juan de Dios en: A.D.C., Varios, leg. 1862, "Cofradía del Santísimo Sacramento y Ánimas" (1671). Alusiones también en la publicación anterior de MORGADO GARCÍA, Arturo, Iglesia y sociedad en el Cádiz del siglo XVIII, Cádiz, Universidad de Cádiz, 1989, p. 216.
} 
es claro el empeño de la esclavitud y archicofradía que ahora analizamos para mantener esta devoción en los sagrarios de las ayudas de parroquia de la ciudad (San Lorenzo, San Antonio, Nuestra Señora del Rosario y San José), además de en la sede episcopal ${ }^{17}$, como lo demuestran las representaciones que a día de hoy se pueden ver en cada uno de ellos.

Sabemos, gracias a Hormigo Sánchez y Sánchez Peña, que el 11 de septiembre de 1760 se hace donación de sitio para la esclavitud y archicofradía en la parroquia de San Antonio ante el escribano público Fernando de la Parra. Y es precisamente en este lugar donde se localiza un libro de cuentas de la cofradía de las ánimas con un frontispicio decorado que, para Alonso de la Sierra, es una clara reutilización de una obra de época anterior, no solo por el estilo de la ornamentación, que para este autor lo dataría hacia finales del XVII, sino también porque la fecha está superpuesta a unos números anteriores. Realizada a tinta y aguada sobre papel, la decoración está formada por varios roleos que flanquean una imagen de la Inmaculada Concepción inserta en una tarjeta en la parte superior; los patronos de Cádiz, san Servando y san Germán a ambos lados de la inscripción "Libro de Cventas de la Cofradia de las Venditas Animas sita en la Santa Yglesia Cathedral de esta Ciudad de Cadiz 1772 A(Ñ)O” y, bajo esta, un pequeño grupo de ánimas desnudas, como corresponde a su tradicional representación iconográfica, entre llamas y socorridas por un par de ángeles, todo ello en otra tarjeta con decoración de roleos, flores y más angelotes alrededor ${ }^{18}$.

Conocemos también un documento, fechado a 16 de diciembre de 1812 y localizado en el Archivo Histórico Nacional, en el que el mayordomo de las cofradías del Santísimo Sacramento y ánimas benditas pedía que fueran aprobadas sus reglas de gobierno $^{19}$.

Los estatutos de 1920 reflejan esta extensión a las otras iglesias gaditanas, hasta copar toda la ciudad, corroborada por los múltiples ejemplos artísticos que a día de hoy se conservan en ellas, relacionados directamente o no con esta congregación. Antes de pasar a detallar cada sede, incluimos algunas referencias relativas a ciertas peculiaridades que consideramos interesantes desgranadas en los diferentes capítulos de estos estatutos.

\footnotetext{
17 ALONSO DE LA SIERRA FERNÁNDEZ, Lorenzo, Pietas Populi Pervivencias, Cádiz, Consejo local de hermandades y cofradías, 2012, pp. 102 y 112.

18 A.H.P.C., 1760, leg. 1467. Of. 8, f. 586, en HORMIGO SÁNCHEZ, Enrique y SÁNCHEZ PEÑA, José Miguel, Documentos para la historia del arte en Cádiz, Cádiz, s.e., 2007, p. 162. ALONSO DE LA SIERRA FERNÁNDEZ, Lorenzo, op. cit., pp. 102-103. En esta página, el autor recoge para este frontispicio, por un lado, la fecha de 1772 y, por otro, la de 1779. Es cierto que la inscripción en la parte de su fecha resulta difícilmente legible, si bien nos parece más que el último número es un 2 y no un 9.

${ }^{19}$ Archivo Histórico Nacional (A.H.N.), Consejos, 12001, exp. 22.
} 
Así, el segundo de ellos exigía a aquellos que pretendieran ingresar en la esclavitud que su edad no superase los sesenta años, que hubieran llevado y mantuviesen una vida de buenas costumbres, asistieran con puntualidad a los actos relacionados con el Santísimo Sacramento y rogasen por las ánimas del purgatorio.

Curiosamente, el capítulo duodécimo, en el que se detallan las obligaciones de los esclavos, no hace ninguna alusión específica a las ánimas. Se dice que debían asistir a los oficios divinos del Jueves y Viernes Santo en la iglesia que se hubiera determinado, orar ante el monumento durante media hora, turnándose todos los esclavos desde la conclusión de los oficios del Jueves hasta el final de los del Viernes; asistir a los cultos que celebrase la esclavitud así como a la sacramentación y sepelio de los hermanos; cumplir anualmente con el precepto pascual, comulgar el día que la esclavitud celebraba su fiesta principal y en las mayores festividades del año y asistir a todo acto en que se reuniera la esclavitud, siempre vestido de negro y con la medalla de esclavo del Santísimo.

Se refiere, en el capítulo número catorce, la celebración de honras generales por los hermanos fallecidos el día de la conmemoración de Todos los difuntos, así como una novena o quinario en sufragio de las ánimas benditas en los días que acordase la junta de la congregación. En este mismo capítulo se especifica que dichos cultos debían celebrarse en la iglesia o parroquia designada por la junta, lo que nos indica que todas las aludidas (Nuestra Señora del Rosario, San Antonio, San Lorenzo y San José) estaban a disposición, junto con la catedral, de la esclavitud. Es más, este mismo capítulo especifica que en San Lorenzo se celebraban las novenas en honor a los patronos de la congregación, san Miguel y la Inmaculada, y los domingos infraoctavas o días designados, misas solemnes con sermón.

Más adelante, en el capítulo diecisiete se dice que "Como quiera que en las Parroquias de Nuestra Señora del Rosario y San Lorenzo no posee esta Esclavitud local alguno, se suplica a los señores Curas de ellas cedan un local con llave para guardar los enseres de las Procesiones Pascuales, a fin de que no sufran extravío”, y continúa con una somera descripción de sus propiedades en diferentes templos, que es como sigue: "En la planta baja de la Contaduría del Excmo. Cabildo Catedral posee la Esclavitud un cuarto de su exclusiva propiedad, la cual habitación, por no ocuparla la Esclavitud más que para guardar los enseres de las procesiones Pascuales, fue cedida, a petición de los señores Contadores, en usufructo y con la condición precisa de entregarla todos los años a la Esclavitud para guardar en ella los útiles de la Procesión Pascual del Sagrario. En la Parroquia de San Antonio, además de la Sala de Juntas, con el departamento de 
Mayordomía y Secretaría y el almacén en la planta baja, es propiedad de la Esclavitud el archivo, cuarto de aguamanil, escaleras que conducen a la sala y la Capilla de Nuestra Señora del Carmen, los que han sido cedidos en usufructo por convenio entre el señor Cura de la Parroquia y la Venerable Esclavitud"20.

En cuanto a las indulgencias concedidas a la esclavitud y archicofradía, algunas se recogen en la primera página de estos mismos estatutos. De ellas destacamos las siguientes: indulgencia plenaria y remisión de todos los pecados para quienes, confesados y comulgados, asistiesen a la oración de cuarenta horas continuas; indulgencia plenaria para los que visitasen la catedral de Cádiz en los días de jubileo de cuarenta horas; privilegio perpetuo para el altar señalado por el obispo de Cádiz, en el que las misas celebradas servirían a las ánimas de los difuntos por quienes se aplicasen; cuarenta días de indulgencia para los fieles que rezasen un avemaría y un padrenuestro ante la lámina insignia de la congregación situada en el sagrario de la catedral; indulgencia plenaria a los que confesados y comulgados, visitasen la iglesia de San Antonio en la dominica siguiente después de Corpus (lo que nos habla de la importancia que ha tenido San Antonio entre todas las parroquias donde quedan alusiones a estas hermandades); y diversas gracias y privilegios concedidos a la venerable archicofradía de la Muerte y Oración de la ciudad de Roma, agregados a los hermanos de la cofradía de la dedicación de San Miguel arcángel y ánimas benditas del purgatorio sita en la catedral de Cádiz, entre las que se encontraban la indulgencia plenaria para todos los que confesados y comulgados visitasen el día de Todos los difuntos la iglesia u oratorio de la misma archicofradía de la muerte y a los que en las mismas circunstancias invocasen de palabra o corazón a Jesús en el momento del fallecimiento.

En los estatutos, antecede a esta relación una estampa en la que se representa la lámina insignia de ambas hermandades con una inscripción que hace referencia a los cuarenta días de indulgencia otorgados por el obispo gaditano Juan Bautista Cervera por el rezo de cada padrenuestro y avemaría (ante esta insignia, como ya se ha explicado). Está fechada en 1778, siendo José Rico el grabador y José Bomar, o Pomar, según parece leerse en la propia pieza, el pintor. En el margen inferior de la página donde aparece esta estampa dentro de los estatutos se incluye, además, otra inscripción que, a fecha de 1911, recoge los cincuenta días de indulgencia otorgados por José María Rancés y Villanueva, obispo de Cádiz, por cada padrenuestro y avemaría rezado por el sufragio de las ánimas del purgatorio.

${ }^{20}$ Estatutos... (op. cit.), p. 20. 
Esta lámina plasma cuatro ánimas penitentes en la parte inferior, estando la de la derecha tocada con mitra episcopal, incidiendo así en la intención edificante de estas representaciones, que pretendían insistir en el hecho de que nadie está libre del pecado ni de su castigo, independientemente de las dignidades que se hubieran ocupado durante la vida terrena. Todas las ánimas se encuentran en actitud suplicante y mirando hacia lo alto, donde resplandece la imagen del Santísimo Sacramento rodeado por cabezas de angelotes (imagen 1).

Muy similar en cuanto a la representación iconográfica y composición -aunque más sencilla- es el óvalo de zinc o plomo localizado en el museo de la parroquia de San Antonio y que claramente perteneció a la cofradía, aunque en este caso parece obra de un artista menos hábil y de época posterior. Así, sobre un fondo de color amarillento, se dispone una custodia sobre nubes y, bajo ellas, una pareja de angelotes; a su vez, en la parte inferior, rodeadas de llamas, un ánima de rostro compungido eleva la vista mientras que otra se tapa el rostro con las manos (imagen 2).
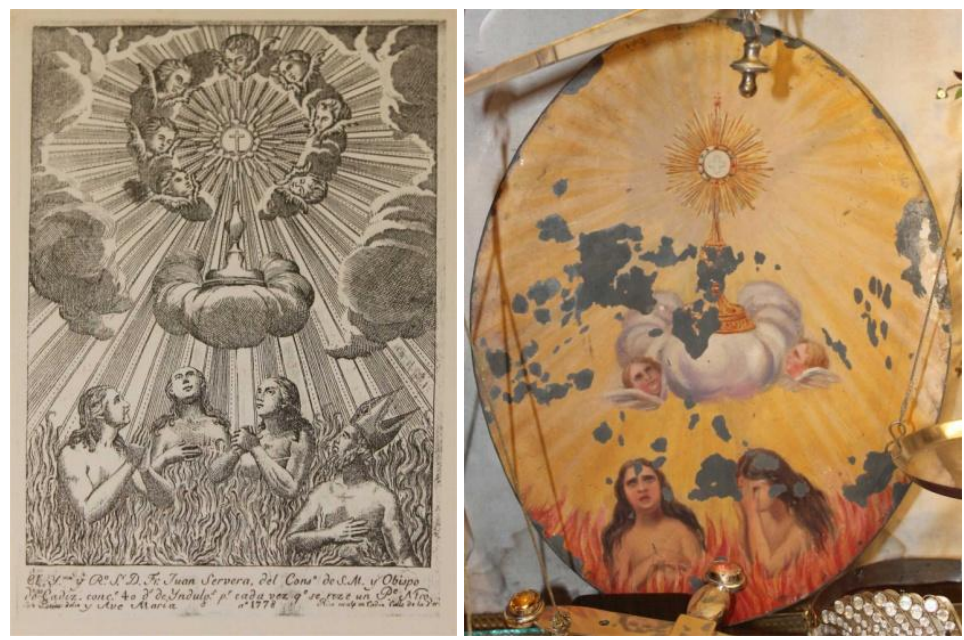

Imágenes 1 y 2. Reproducción de la lámina insignia de la esclavitud del Santísimo Sacramento y archicofradía de las benditas ánimas y óvalo de la misma congregación.

Museo de la parroquia de San Antonio

Este mismo museo custodia algunos ropajes, la balanza, corona y espada pertenecientes al san Miguel arcángel patrono de la archicofradía que hoy se encuentra en el retablo de las ánimas de la iglesia de San Lorenzo, de la que hablaremos a continuación. 
Todavía en San Antonio se localiza un lienzo de apreciable tamaño (220 x 246 cm), a pesar de que probablemente esté recortado en su parte superior, fechado hacia 1700. Alonso de la Sierra ${ }^{21}$ pensó que podría haber sido un encargo de esta cofradía, si bien después de haber hablado con un anticuario de la ciudad hemos sabido que fue vendido por este al párroco de la iglesia y nada tiene que ver, por lo tanto, con la esclavitud y archicofradía. La parte inferior aparece ocupada por multitud de ánimas desnudas de ambos sexos y diversas edades que son reconfortadas por cuatro ángeles vestidos con túnica y manto; sobre todos ellos, aquellas que han sido salvadas se elevan hacia el cielo vestidas de blanco y acompañadas por otros ángeles, niños y no mancebos como los que ocupan la zona media del lienzo.

Siguiendo con el museo de San Antonio, aquí se guarda un cuadro de la Virgen del Carmen y, en la sacristía, uno más con el asunto iconográfico conocido como ánimas del Callao.

En cuanto al primero, se trata de un óleo sobre lienzo de calidad modesta y en mal estado de conservación, probablemente decimonónico, que representa a la Virgen del Carmen en la parte superior y varias ánimas entre llamaradas en la inferior. María, aparentemente sentada sobre un trono de nubes con varios ángeles bajo ella, suele representarse a partir del siglo XVIII como vemos aquí2 ${ }^{2}$, es decir, como Madre y reina, con Niño y corona, y vistiendo el hábito carmelita, compuesto por una túnica marrón cubierta por el manto blanco y un broche con el escudo de la orden, en el que aparece el monte Carmelo -lugar donde discurrió el episodio de Elías, fundador de la orden, y los sacerdotes de Baal- de color marrón sobre fondo blanco y tres estrellas de seis puntas, una blanca en el centro de la montaña y las otras dos a ambos lados, marrones. Sujeta al Niño, inclinado hacia las ánimas, con su brazo izquierdo mientras que el derecho se extiende hacia abajo, sosteniendo el escapulario, en actitud de socorrer a las almas penitentes, de ambos sexos y diferentes edades, localizadas a sus pies. Entre estas destaca una figura masculina alzando su mano para asir el escapulario ofrecido por María. Aunque no es el caso, no es infrecuente que la Virgen ocupe el centro de la composición, quedando reservada la parte más alta para una representación celestial.

La importancia de esta advocación mariana en relación con las ánimas del purgatorio se remonta al 16 de julio de 1250 cuando san Simón Stock, general de los carmelitas, recibe la visita de María, que le entrega el escapulario y le promete la salvación

${ }^{21}$ ALONSO DE LA SIERRA FERNÁNDEZ, Lorenzo, op. cit., p. 112.

22 DÍAZ VAQUERO, María Dolores, La Virgen en la escultura cordobesa del barroco, Córdoba, Monte de Piedad y Caja de Ahorros de Córdoba, 1987, p. 107. 
del fuego eterno para todo aquel que usara el hábito de la orden, anunciando de esta manera su intercesión en el artículo de la muerte. La entrada en el Paraíso se ve así asegurada por el escapulario, símbolo del hábito carmelita, en conexión con la tradición medieval que garantiza el paso a la Gloria si se pertenece a una orden. El desarrollo iconográfico de la Virgen del Carmen como intercesora por las ánimas del purgatorio se ha visto alimentado por el "privilegio sabatino", según el cual, la Virgen haría salir del purgatorio el sábado posterior al día de su muerte a todos aquellos que, habiendo muerto en gracia, hubieran llevado el escapulario durante su vida. Dicho privilegio parte de Balduino de Lessio (muerto en 1483), después de que diera a conocer una bula de Juan XXII fechada el 3 de mayo de 1317, en la que declaraba haber tenido esta revelación de la propia Virgen $^{23}$ (imagen 3).

Por otro lado, el cuadro con las ánimas del Callao presenta una interesante complejidad iconográfica, con todo un elenco de santos -entre los que se encuentran la Magdalena, san Francisco Javier, san Juan Nepomuceno, san José, san Agustín, san Juan Evangelista, san Antón, san Francisco y san Antonio de Padua, entre otros-, rodeando al Crucificado sobre el cual aparece la Inmaculada Concepción coronada por la Trinidad que se dispone en la parte más alta del lienzo. A su vez, la figura de la Virgen está flanqueada por sus padres, san Joaquín y santa Ana. La alusión a las almas penitentes es mínima, y se reduce a tres pequeñas figuritas de las que solo se aprecian sus cabezas y brazos elevados bajo la cruz. En la parte inferior del lienzo se incluyen sendas tarjetas donde se especifica quién pintó la obra (parece que se recoge el nombre de Luis de María F. Campos), que la realizó en Cádiz en 1877, estando dedicada a un amigo del artista cuyo nombre no puede leerse por estar cortada la inscripción en su parte inferior. Sigue un original de 1762 que fue tocado a la imagen de la Virgen de Guadalupe en 1765 y se recogen también las indulgencias concedidas por el arzobispo de México, Manuel José Rubio y Salinas (imagen 4).

23 Iconografía y arte carmelitano, Granada, Junta de Andalucía, Turner, 1991, p. 20; CARRASCO TERRIZA, Manuel Jesús y GONZÁLEZ GÓMEZ, Juan Miguel, Escultura mariana onubense, Huelva, Excelentísima Diputación Provincial de Huelva, 1992², p. 468 (en muchos otros lugares se fecha esta bula el 3 de marzo de 1322). 

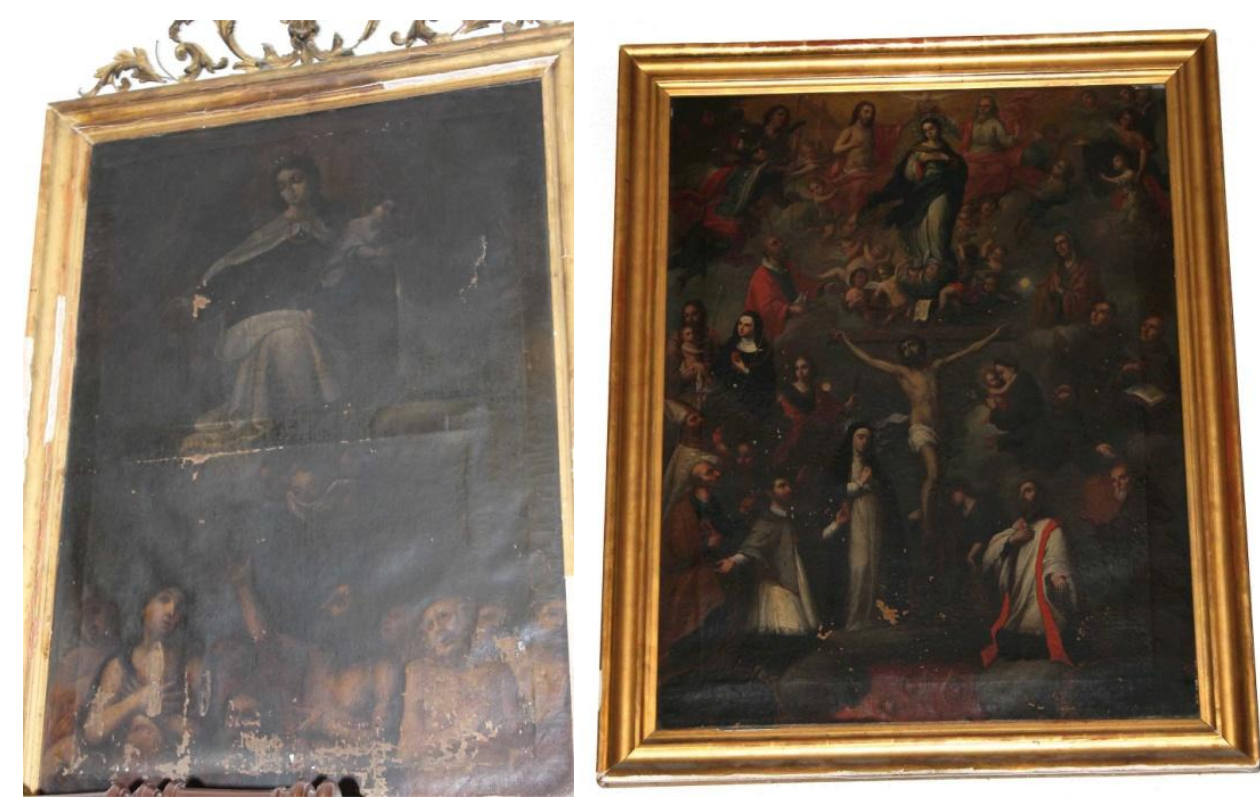

Imágenes 3 y 4. Virgen del Carmen con las ánimas y Ánimas del Callao. Iglesia de San Antonio

Además, en la parroquia de San Lorenzo quedan otros restos de esta devoción y de la propia cofradía. Riquelme Gómez ${ }^{24}$, en su estudio sobre las representaciones pictóricas en las cofradías de ánimas murcianas, especifica que este tipo de congregaciones estaban dedicadas a la Virgen o a ciertos santos, especialmente los relacionados con los últimos momentos de la vida, que se convertían en patronos de la cofradía en cuestión. En el caso que estamos estudiando, la esclavitud y archicofradía gaditana estuvo bajo el patronazgo de san Miguel arcángel. Todavía hoy se conserva su talla de vestir, atribuida a José Montes de Oca (imagen 5), en la hornacina central del retablo localizado en el muro frontal del lado del evangelio del crucero, que hasta el siglo XIX fue el sagrario del mencionado templo de San Lorenzo, cedido como tal a la cofradía en $1727^{25}$. Una losa dispuesta en el suelo ante este retablo datada en 1728 incluye una inscripción en la que se afirma que era esta cofradía la dueña tanto de la capilla como de la bóveda. No extraña la elección de este arcángel como protector de una hermandad de ánimas: su figura, con la balanza en la mano (aunque esta talla porta una, otra más se custodia actualmente en el museo de la parroquia de San Antonio), estuvo unida desde el Medievo al juicio que todo hombre deberá superar y en el

\footnotetext{
${ }^{24}$ RIQUELME GÓMEZ, Emilio Antonio, "Santos intercesores del purgatorio. Representaciones pictóricas en las cofradías de ánimas murcianas", El culto a los santos: cofradias, devoción, fiestas y arte, Madrid, Ediciones Escurialenses, 2008, p. 500.

${ }^{25}$ ALONSO DE LA SIERRA FERNÁNDEZ, Lorenzo, Guía artística de Cádiz y su provincia, vol. 1, Sevilla y Cádiz, Fundación José Manuel Lara y Diputación provincial de Cádiz, 2005, p. 164. Y "Decreto 90/2009 de 14 de abril, por el que se inscribe en el Catálogo General del Patrimonio Histórico Andaluz como Bien de Interés Cultural, con la tipología de Monumento, la iglesia de San Lorenzo Mártir, en Cádiz”, BOJA, 27 de abril de 2009, p. 63 [En línea]. Disponible en: http://www.juntadeandalucia.es/boja/2009/79/boletin.79.pdf [Consulta: 15/06/2013].
} 
que se salvará o condenará eternamente. El mencionado Riquelme Gómez ${ }^{26}$ destaca que después de Trento, san Miguel sería tenido en cuenta como protector de las almas, conductor y abogado de las mismas pero que, una vez llegado el siglo XVIII, su desempeño como defensor ante los peligros de la muerte, pasaría a san Rafael. Sin embargo, la archicofradía que estudiamos lo mantuvo como su patrón a lo largo del tiempo y existen imágenes de este mismo arcángel que sostiene su balanza con un ánima en cada uno de los platillos, como el que se localiza en la iglesia mayor de San Fernando.

No será la única alusión a las ánimas en este templo puesto que la capilla del Pilar guarda una advocación aragonesa, la del Cristo de Ribota, en un lienzo de principios del XVIII en el que el Crucificado tiene a sus pies, flanqueándolo, una pareja de ánimas en actitud orante $^{27}$ (imagen 6).

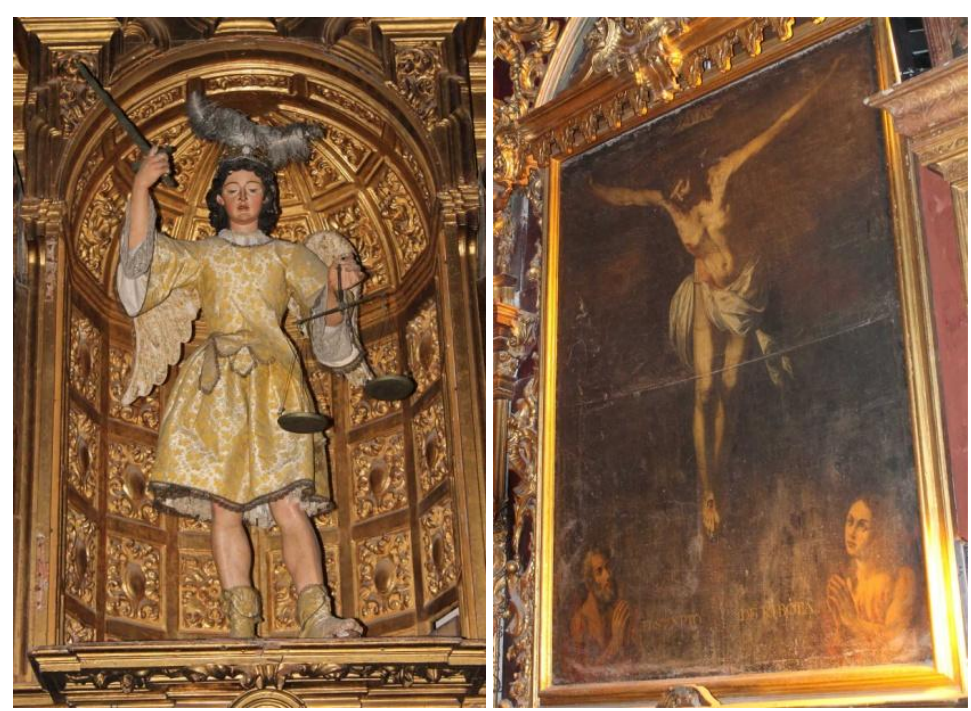

Imágenes 5 y 6. San Miguel, de José Montes de Oca en el retablo del arcángel y Cristo de Ribota. Iglesia de San Lorenzo

Aún hay dos parroquias más en las que se pueden ver ciertos elementos relacionados con la devoción a las ánimas: en la del Rosario queda un lienzo del XVIII con esta advocación mariana entre santo Domingo y san Francisco, a quienes les entrega sendos rosarios, que hace poco ha protagonizado una polémica restauración.

La Virgen del Rosario, devoción impulsada por dominicos y capuchinos mientras que los franciscanos apoyaron el desarrollo del culto a la Inmaculada, tiene una gran importancia en el sentir religioso gaditano: por un lado, fue nombrada patrona de Cádiz y,

\footnotetext{
${ }^{26}$ RIQUELME GÓMEZ, Emilio Antonio, op. cit., p. 503.

27 Incluye la inscripción "El Smo. Xpto. De Ribota". Aparece recogido como "Cristo de Ribolta" en el "Decreto 90/2009 de 14 de abril (...)", op. cit., p. 64 y en ALONSO DE LA SIERRA FERNÁNDEZ, Lorenzo, op. cit., 2005, p. 165.
} 
por otro lado, los rosarios callejeros, que se dieron desde finales del XVII gracias a fray Pablo de Cádiz, alcanzaron su máximo esplendor en la siguiente centuria. Finalmente, la disposición del 1 de octubre de 1756 de celebrar solemnemente su fiesta en recuerdo de su intercesión en el maremoto de 1755, supondría el impulso definitivo para su culto ${ }^{28}$.

Aunque la devoción al rosario se dio con Alain de la Roche hacia 1470, la tradición afirma que fue santo Domingo quien recibió de manos de la Virgen el rosario para luchar contra la herejía albigense. La representación iconográfica de este santo sigue, en la presente obra, las pautas habituales, con el hábito blanco y el manto negro, colores simbólicos de la pureza y la austeridad, con tonsura y barbado. Al otro lado de la Virgen, san Francisco de Asís, con el hábito de su orden y el cíngulo con los tres nudos alusivos a los votos de la misma. No es extraño que ambos fundadores aparezcan juntos, incluso abrazándose, pues según los hagiógrafos, se encontraron en Roma cuando santo Domingo acudió para lograr la aprobación de su orden. Al día siguiente de que este soñara con Cristo dispuesto a castigar a la humanidad por su orgullo, su avaricia y su lujuria, y como su Madre lo apaciguara mostrándole a los dos monjes que predicarían obediencia, pobreza y castidad, ambos santos se encontraron, abrazándose como señal de que entre los dos lograrían imponer aquellas virtudes ${ }^{29}$.

El último lugar relacionado con la esclavitud y archicofradía es la parroquia de San José. En ella, la capilla de los pies de la nave del evangelio guarda un relieve con la Virgen del Carmen como intercesora por las ánimas que, parece, debió de salir de algún taller en serie, puesto que se ha encontrado, con algunas diferencias de tamaño y composición, en la iglesia de San Francisco y en la iglesia mayor de San Fernando e, incluso, fuera de Cádiz, en Teba (Málaga), sabemos de la existencia de otro relieve exactamente igual. Según Mósig Pérez, el de San Fernando se adquiere en 1912 mientras que los localizados en la parroquia que nos ocupa y en San Francisco parece, en cambio, que se colocaron en su lugar tras los asaltos sufridos en 1931 y $1936^{30}$.

\footnotetext{
${ }^{28}$ MORGADO GARCÍA, Arturo, op. cit., 1989, pp. 201-202.

29 GONZÁLEZ GÓMEZ, José Miguel y CARRASCO TERRIZA, Manuel Jesús, op. cit., pp. 483-484. RÉAU, Louis, Iconografía del arte cristiano. Iconografía de los santos A-F, Barcelona, Ediciones del Serbal, 1997, pp. 394-400; para san Francisco de Asís: pp. 544-563.

${ }^{30}$ MÓSIG PÉREZ, Fernando, Historia de las hermandades y cofradías isleñas, San Fernando, s.e., 2005, p. 129. En concreto, el retablo original de la iglesia del convento de San Francisco, desapareció en 1931, siendo sustituido por este de la Virgen del Carmen con las ánimas, según ALONSO DE LA SIERRA FERNÁNDEZ, Lorenzo, El retablo neoclásico en Cádiz, Cádiz, Diputación Provincial, 1989, p. 113.
} 


\section{SAN NICOLÁS DE TOLENTINO. CONVENTO DE SAN AGUSTÍN}

Patrón de los agonizantes y de las ánimas del purgatorio, probablemente san Nicolás de Tolentino $^{31}$ es uno de los santos más relacionados con estas últimas, y varias son las noticias que podemos aportar en Cádiz relativas al patronazgo que nos ocupa, procedentes del convento de San Agustín.

Aunque su nacimiento tuvo lugar en Castro de Sant'Angelo, cerca de Fermo, en Italia, en 1249, se le conoce como "de Tolentino" por su estancia en aquel convento, después de haber pasado por otros, en el que falleció en 1305. Sus padres, estériles y ancianos, lugar común en las hagiografías, lograron concebirlo gracias a sus oraciones y a la visita que hicieron a la tumba del santo homónimo en Bari, bautizándole con el mismo nombre de aquel que les concedió la gracia del nacimiento.

Perteneció nuestro protagonista a la orden de los ermitaños de San Agustín, alcanzando fama por sus sermones y milagros, entre los que destaca el que cuenta cómo los monjes de su convento, viendo su debilidad física debida a los constantes ayunos y penitencias y su obstinada negativa a comer carne, y aconsejados por el médico, le prepararon una perdiz asada que llevaron troceada a su celda. El santo, no solo no probó bocado, sino que resucitó al animal, que escapó volando, pasando, por otro lado, a ser uno de los atributos que lo identifican iconográficamente.

La leyenda narra también que cuando acudía a rezar a la iglesia después de que hubiese anochecido, una estrella iluminaba su camino, de manera que a veces este astro orna su pecho o se multiplica, salpicando el hábito negro ajustado mediante un cinturón de cuero con el que, como agustino, se viste; además, se le puede representar con un crucifijo y una vara de azucenas en la mano o con algunos panes que puede llevar un ángel, aludiendo a este alimento que repartía entre los pobres (él mismo curó en una ocasión gracias a un pedazo de pan que le ofreció la Virgen) y que, en cierto momento, llegó a convertir en rosas para evitar que se descubriera la acción caritativa que estaba llevando a cabo. De aquí surgió la costumbre, en los conventos agustinos, de distribuir el pan de san Nicolás -que debía comerse mojado en un vaso de agua- el día de su fiesta.

Un episodio de su vida ocurrido en el monasterio de Villazanes, cerca de Pésaro, justifica su patronazgo sobre las ánimas del purgatorio. Se dice que estando en su celda oyó

\footnotetext{
${ }^{31}$ Las breves líneas que incluimos sobre su vida están tomadas de: RÉAU, Louis, Iconografía de los santos G-O (Iconografía del arte cristiano, t. 2, vol. 4), Barcelona, Ediciones del Serbal, 1997, pp. $442-444$ y SICARDO, Joseph, Vida, y Milagros del glorioso San Nicolás de Tolentino (...), Madrid, Imprenta de Manuel Ruíz de Murga, 1701. En esta última se le califica de "sol", tanto en su vida como en su muerte por sus múltiples virtudes, y por ello, se dice, lleva dicha figura en el pecho.
} 
la voz de fray Peregrino de Osmo, a quien había conocido en vida, rogándole que le celebrase una misa para poder aliviar su estancia en el purgatorio, pero como el santo se excusara, aludiendo a las obligaciones que le impedían hacerlo, el alma en pena quiso que le acompañase para que pudiera ver la situación de quienes se encontraban sufriendo en aquel lugar. Tras la visión del fuego que consumía a las ánimas, al día siguiente Nicolás pidió al prior que le permitiese celebrar todas las misas que debía oficiar aquella semana por las almas del purgatorio, como así ocurrió, dedicándose además durante ese tiempo a orar y hacer penitencia a favor de las mismas. Pasados ocho días se le apareció de nuevo fray Peregrino acompañado por algunas de las ánimas que pudo ver Nicolás en su momento, para agradecerle al santo todas las acciones que había realizado, gracias a las cuales se encontraban libres de su penitencia.

En recuerdo de la semana que dedicó sus misas a estas almas, para ayuda de las benditas ánimas se empezaron a celebrar las siete misas de san Nicolás de Tolentino, que estaban perfectamente reguladas, puesto que quien las encargaba debía comulgar en la primera, celebrada en lunes, y, junto al oficiante que había de ser un fraile agustino, ayunar a pan y agua el lunes, miércoles y viernes u ofertar limosnas y rezos para evitar el ayuno. Además, únicamente se podían celebrar en un convento de la orden y en altares dedicados al santo, siendo las seis primeras, del santo, rezadas, y la última cantada ${ }^{32}$.

El convento de San Agustín de Cádiz, fundado en 1617, conserva un par de representaciones suyas, que ahora analizaremos, y además fue también la sede de una hermandad del santo y las ánimas.

Según la documentación, en 1649, Agustín Díaz de Acosta pagaba 300 ducados de plata para costear la capilla del santo, que después pasaría a ser de santa Rita; tras la creación de la hermandad en 1655, el convento les cede por 600 ducados la capilla localizada entre la de Santo Tomás de Villanueva (imagen no conservada) y la del Crucificado (el Cristo de la Buena Muerte del que hablaremos más adelante y que hoy se sitúa en el crucero), segunda del lado del evangelio, empezando por los pies, protocolizándose en 1671. Entre los miembros de la hermandad aparece Damián Machado de Herrera, retablista que se ha supuesto artífice del retablo lígneo primigenio y, puesto que carecían de una imagen del santo italiano para poder colocar en el mismo, el capitán Pedro de Olarte y

\footnotetext{
32 LOBERA Y ABIO, Antonio, El porqué de todas las ceremonias de la Iglesia y sus misterios. Cartilla de prelados y sacerdotes (...), Barcelona, Imprenta de los Consortes Sierra y Martí, 1791, p. 649 y MARTíNEZ GIL, Fernando, Muerte y sociedad en la España de los Austrias, Cuenca, Universidad de Castilla la Mancha, 2000, p. 242.
} 
Urrea les cedió una pequeña de su propiedad, que el 21 de agosto de 1687 era vendida por 25 pesos escudos de plata mediante escritura dada ante Juan García Núñez ${ }^{33}$.

La hermandad, por su parte, fue fundada en 1655 y renovada en 1725, como nos informa el documento que recoge las reglas de la misma, firmado el 21 de diciembre de este último año ${ }^{34}$.

Varios son los artículos o capítulos de estas reglas que ofrecen aspectos importantes en relación con la devoción a las ánimas. Así, por ejemplo, en el primero de ellos se menciona la bula otorgada por Clemente X (1590-1676) el 1 de julio de 1670 según la cual obtenían indulgencia plenaria todos aquellos que, habiendo confesado y comulgado, entraran a formar parte de la hermandad; igual gracia obtenían los hermanos que en el momento de morir recibieran los sacramentos o con que, realmente contritos, invocasen el nombre de Jesús de palabra o pensamiento. No eran las únicas: también plenarias eran las indulgencias que los hermanos obtenían el día de la fiesta del santo si, confesados y comulgados, acudían a rezar a la iglesia de San Agustín, mientras que haciendo lo mismo los días de san Felipe y Santiago, san Andrés apóstol, Todos los santos y en el día en el que la hermandad celebrase las honras por los fallecidos, eran siete años y siete cuarentenas de perdón los que se lograban. Finalmente, para ganar sesenta días de perdón y absolución de las penitencias impuestas, era necesario, entre otras acciones detalladas en este primer artículo, asistir a los oficios divinos en el templo o rezar cinco padrenuestros y cinco avemarías por las ánimas de los hermanos difuntos.

El documento original de esta bula se guardaba en el archivo de la hermandad, pero, para conocimiento de todos los fieles, se colocó una tabla -que debía renovarse siempre que fuese necesario- en la puerta de la capilla del santo, que detallaba todas las indulgencias y modo de obtenerlas.

Además de celebrar el 10 de septiembre, festividad del santo, todos los lunes del año había misa y procesión por las ánimas del purgatorio, lo que no debe extrañar, pues ya

\footnotetext{
33 A.H.N., Clero, libro 1773, "Protocolo de Fundación del Convento de San Agustín de Cádiz", ff. 7-20, en ESPINOSA DE LOS MONTEROS SÁNCHEZ, Francisco, "La cofradía de la Humildad y Paciencia de Cádiz en el siglo XVII. Nuevas aportaciones documentales", Cádiz cofrade. Historia y memoria [en línea]. Disponible en: http://www.cadizcofrade.net/historia/humildadsxvii.htm\#sdendnote16sym [Consulta: 29/06/2013] y PATRÓN SANDOVAL, Juan A. y ESPINOSA DE LOS MONTEROS SÁNCHEZ, Francisco, "La obra del escultor genovés Jacome Baccaro para la iglesia parroquial de San Francisco en Tarifa (y II)", Aljaranda, 68 (2008), p. 25.

34 Reglas de la Hermandad del Sr. Sn. Nicolas de Tolentino y las Benditas animas del purgatorio, sita en el Convento del Sr. Sn. Agustin de esta Ciudad de Cadir fundada en el año de 1655 y renovada en el de 1725, A.H.P.C., Gobierno Civil, Caja 272. En ESPINOSA DE LOS MONTEROS SÁNCHEZ, Francisco, "La cofradía de la Humildad y Paciencia de Cádiz (...), op. cit., se dice que la fundación tiene lugar en 1655 y sus reglas son aprobadas en 1715 -clara errata-, sobreviviendo la hermandad hasta mediados del siglo XIX.
} 
vimos que es el día para tales celebraciones. Este punto se ve ampliado en el capítulo catorce, cuando se dice que esta misa debe ser cantada y de réquiem.

El capítulo segundo habla de la petición de demanda y limosna para san Nicolás de Tolentino y las ánimas del purgatorio en la iglesia de San Agustín a la que estaban obligados todos los hermanos, y se complementa con el décimo, en el que se establecía que se recogería los días de fiesta, encargándose cada mes un miembro diferente según el acuerdo al que se hubiera llegado en el cabildo general de elecciones. En él, se repartirían los meses del siguiente año, dando a elegir primero al prior, después a los oficiales y consiliarios para acabar con el resto de los hermanos, qué mes preferían. Esta misión obligatoria podía salvarse dando a cambio una limosna de, como mínimo, quince reales de vellón, que se emplearía en los gastos ocasionados con motivo de la fiesta del santo.

$\mathrm{El}$ tercero, por su parte, exige a los futuros hermanos que sean cristianos viejos y de buena vida, que no hubieran sido castigados por la Inquisición ni la justicia y no hubiesen ejercido nunca oficios viles. Además, frente a las primitivas reglas, que limitaban el número de congregantes, en las de 1725 se declaraba que no existía ya un número máximo de hermanos.

Y aún hay dos puntos más interesantes para nuestro estudio, que son el trece y el catorce. En el primero de ellos se menciona la concurrencia que deben tener los miembros de la hermandad en la celebración del día de Todos los difuntos, mientras que el segundo dictamina que el lunes siguiente a la mencionada fiesta, se celebre aniversario por las almas del purgatorio, poniendo en la iglesia agustina un túmulo elevado cubierto por el paño de la hermandad, que estaba obligada a asistir al oficio, misa, responso y procesión con velas blancas y su insignia. Además, el mismo día se diría misa rezada por todos los sacerdotes del convento en beneficio de las ánimas.

Con la renovación del templo en época neoclásica, se crean casi todos los retablos que han llegado hasta nuestros días. El dedicado a nuestro santo se dispone en la quinta capilla del lado del evangelio. Fechado a mediados del XVIII, está realizado con mármoles genoveses y presenta una movida composición de columnas salomónicas y otros elementos barrocos; Lorenzo Alonso de la Sierra ha reseñado la coincidencia formal de su mesa con la diseñada por Alessandro Aprile para el oratorio del Palazzo Negrone en Génova y Ponz lo criticó diciendo "Ninguna prueba mejor del mal gusto que las alabanzas dadas a esta obra que merecía quitarse de la vista y prohibir la entrada en el reino de mamarrachos de esta clase". El San Nicolás de Tolentino que cobija en su interior es una talla policromada de 
cronología similar, que podría situarse en torno a $1760^{35} \mathrm{y}$, por lo tanto, no se trata de la escultura que estuvo en el primer retablo, sino que la sustituyó al tiempo que se renovaba este.

La autoría de esta talla en madera de bulto redondo no está clara, y los diversos autores que la han estudiado plantean hipótesis diversas. Así, para Patrón Sandoval y Espinosa de los Monteros Sánchez, su canon alargado, sus cejas arqueadas, la manera en la que se ha modelado su boca o la similitud entre las ánimas que lo acompañan y las presentes en la Virgen del Carmen de la iglesia parroquial de San Francisco de Tarifa, les lleva a relacionar esta pieza con la producción de Jacome Baccaro aunque, respecto a la fecha de su creación, en un primer momento afirman que pudo realizarse hacia 1770-1775 y líneas después en su artículo recogen el año de 1762. Sin embargo, Moreno Arana discrepa contundentemente en cuanto a esta atribución, si bien no añade ninguna otra hipótesis al respecto ${ }^{36}$.

La escultura muestra al santo según la manera habitual de representarlo: imberbe, nimbado y con el hábito negro constelado de estrellas ${ }^{37}$, entre las que destaca la que se localiza en su pecho, de mayor tamaño. En este caso todas ellas presentan seis puntas, si bien no en la forma del conocido hexagrama, que alude al escudo de David (scutum Davidis) o al sello de Salomón (sigillum Salomonis). Aparte de las interpretaciones que ya se han mencionado, acerca de la estrella que le guiaba de noche o de la consideración del santo como "sol" que iluminaba a la humanidad con sus virtudes, las mismas estrellas se han considerado, desde épocas antiguas, como símbolos, muchas veces en relación con la divinidad -que origina el movimiento de las estrellas y de quien depende la creación entera-. De este modo, al referirse a los egipcios, Horapolo en el siglo $\mathrm{V}$ decía que pintaban una gran estrella para designar al dios del universo. Igualmente son símbolo de lo divino y atributo de algunas divinidades planetarias en el arte profano, mientras que en muchas mitologías se considera que son las almas de los difuntos admitidos en el cielo -qué mejor

\footnotetext{
35 ALONSO DE LA SIERRA FERNÁNDEZ, Lorenzo, op. cit., 2005, pp. 91 y 93; PONZ, Antonio, Viage de España en que se da noticia de las cosas más apreciables y dignas de saberse que hay en ella, t. XVII, Madrid, Viuda de D. Joaquin Ibarra, 1792, p. 342 y ALONSO DE LA SIERRA FERNÁNDEZ, Lorenzo, "Mármoles italianos en Cádiz durante el siglo XVIII. Un retablo de Alessandro Aprile”, Atrio, 7 (1995), p. 62.

36 PATRÓN SANDOVAL, Juan A. y ESPINOSA DE LOS MONTEROS SÁNCHEZ, Francisco, op. cit., p. 24-25 y MORENO ARANA, José Manuel, "La impronta genovesa en la escultura jerezana de la segunda mitad del siglo XVIII", Revista de historia de Jerez, 16/17 (2010/2012), p. 23.

37 Según GONZÁLEZ VALDÉS, Juan, Apéndice al diccionario enciclopédico de Teología que escribió el abate Bergier, Madrid, Imprenta de Don Tomás Jordán, 1832, p. 15: "El hábito de estos religiosos consiste en una túnica y escapulario blancos dentro de casa; y cuando van a coro, o han de salir fuera, se ponen una especie de cogulla negra, y por encima una gran capilla, que es redonda por delante y remata en punta por detrás hasta el ceñidor, que es de correa negra”.
} 
elemento, por lo tanto, para un personaje que ayuda a alcanzar la gloria ${ }^{38}$. En cualquier caso, la aparición de estos astros en relación con personajes sagrados no es nueva: santo Domingo, san Vicente Ferrer, san Hugo de Grenoble o la Inmaculada Concepción se identifican también por llevar este elemento, si bien de modo y en número diferente.

Apoyando sus pies sobre un lecho de nubes, el santo sostiene en su mano derecha una correa; se trata de uno de los tres instrumentos más representados, junto con el escapulario de la Virgen del Carmen y el cordón de san Francisco, como medio de salvación de las llamas del purgatorio para las almas que en él penan ${ }^{39}$. Flanqueando su figura aparecen una pareja de ánimas masculinas a su derecha, una de las cuales hace ademán de asir el mencionado cinturón, y otra pareja, femenina, a su izquierda, todas ellas en actitud suplicante y devoradas por las llamas que ocultan la parte inferior -no tallada- de sus cuerpos. Su otra mano debió de portar algún elemento, probablemente una bandeja en la que se disponía la perdiz que resucitó, hoy perdido, pues se encuentra extendida y con la palma hacia arriba (imagen 7).

Poco difiere la otra representación iconográfica de este santo que se encuentra en la iglesia de los agustinos. Se trata de un lienzo fechable a principios del XVIII dispuesto en el ático del retablo de San Juan Bautista, situado en el quinto tramo de la nave de la epístola, comenzando desde los pies. Alonso de la Sierra apunta al desconocimiento de la imagen titular que ocupaba en origen la hornacina de este retablo fechado alrededor de 1797, aunque especifica que en ella han estado sucesivamente las imágenes de santa Rita, Nuestra Señora de Fátima y, en la actualidad, san Juan Bautista ${ }^{40}$. En cualquier caso, la pintura que nos concierne ofrece a un santo de aspecto casi exacto al de la talla comentada. Los rasgos de su rostro coinciden, la disposición del cabello, con tres partes bien diferenciadas en el centro de la frente y los laterales de la cabeza, aunque no es ajena a algunas otras representaciones suyas, también, y hasta la decoración de la vestimenta se repite, con sus bordes de flores y roleos dorados, resultando especialmente llamativo el modo de orlar el bajo de la túnica, casi idéntico. En su mano derecha, de nuevo, la correa, esta vez agarrada por una de las ánimas que lo flanquean suplicando por su intercesión, las cuales, a diferencia de la escultura, son tres a cada lado del santo y con una única femenina

\footnotetext{
38 V.V.A.A, "Étoiles", Encyclopédie des Symboles, París, La Pochothèque, 1996, pp. 241-242; TERVARENT, Guy de, "Estrella", Atributos y símbolos en el arte profano. Diccionario de un lenguaje perdido, Barcelona, Ediciones del Serbal, 2002, pp. 249-250.

39 ARRATIA MARTÍN, Victoria, Las ánimas del purgatorio en la provincia de Valladolid, una devoción popular, Valladolid, Diputación Provincial, 1999, p. 60.

40 ALONSO DE LA SIERRA FERNÁNDEZ, Lorenzo, op. cit., 1989, p. 105. En la nota número 99 especifica que el detalle de la imagen de santa Rita viene reflejado en el Inventario del convento de San Agustín, 1900 (A.D.C., sección varios, legajo 496).
} 
entre todas ellas. En su mano izquierda porta la bandeja sobre la que reposa la famosa ave protagonista de su milagro, que en este caso parece más paloma que perdiz.

El hecho de que fuera perdiz y no otro animal puede tener también su interpretación simbólica relativa a la Eucaristía, más en este caso, al tratarse de uno de los principales intercesores por las ánimas condenadas a sufrir en el purgatorio. Perdices y codornices han sido víctimas de sacrificio a lo largo de la historia, siendo especialmente utilizadas en las diferentes mancias que pretendían leer el futuro en sus entrañas y, para los hebreos en Egipto, las segundas fueron su alimento, convirtiéndose en prefiguración eucarística. Además, por ser los campos de vides uno de sus hábitats favoritos, el arte paleocristiano representó perdices, racimos de uvas y hojas de parra con este mismo sentido $^{41}$, si bien en época románica pasaron a tener una connotación negativa. Quizá por ello su representación se sustituye por la de una paloma o tórtola, de significación sacramental mucho más clara y evidente para todos ${ }^{42}$.

Probablemente el elemento más sorprendente es el nimbo estrellado que circunda la cabeza de nuestro protagonista, atributo específico de san Juan Nepomuceno, cuyo cuerpo muerto flotó en el río Moldava rodeado por cinco estrellas o llamaradas que se plasmaron plásticamente en forma de nimbo, y de la Inmaculada, como se dijo (imagen 8).
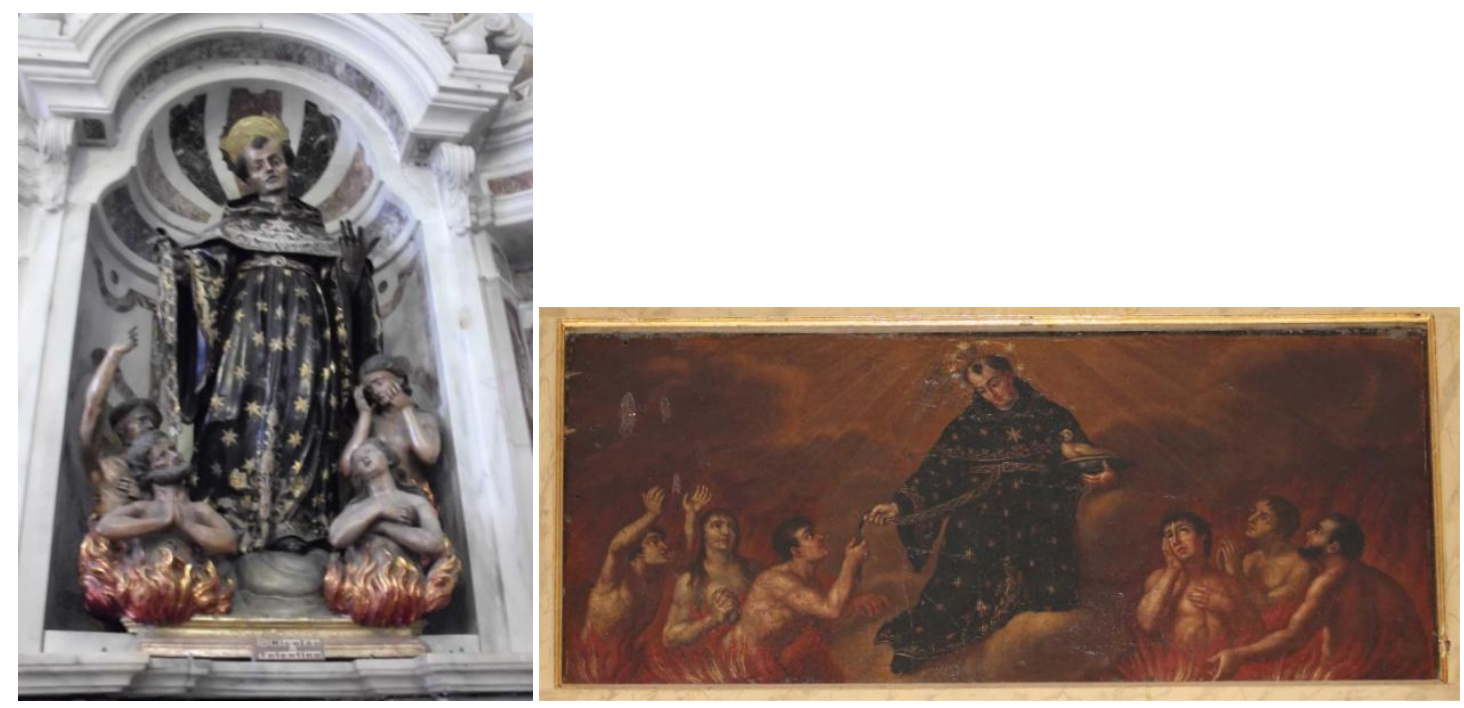

Imágenes 7 y 8 . Retablo de San Nicolás de Tolentino y pintura del ático del retablo de San Juan Bautista. Convento de San Agustín

\footnotetext{
${ }^{41}$ CHARBONNEAU-LASSAY, Louis, El Bestiario de Cristo. El simbolismo animal en la Antigüedad y la Edad Media, vol. II, Barcelona, Liberduplex, 1997, p. 505.

42 Para profundizar en este asunto, vid.: GONZÁLEZ TORRES, Javier, “Tórtola”, Emblemata Eucharistica. Símbolos animados de la iconografía cristológica y sacramental, Málaga, Universidad de Málaga, 2009, pp. 187-193.
} 
Todavía en esta iglesia se puede encontrar una referencia más a las ánimas que refleja la importancia que han tenido las almas de los difuntos para la Iglesia católica. Se trata del Cristo de la Buena Muerte, fechado en 1649 y conocido en origen como Cristo de Ánimas o de San Agustín porque se encargó para ocupar la capilla de enterramiento de los frailes. Tallado en madera policromada por un artista anónimo, aunque Lorenzo Alonso de la Sierra ve similitudes con maestros como Alonso Cano o Felipe de Ribas, entre otros -y en época más reciente se está apuntando a la escuela italiana-, actualmente ocupa el testero del lado derecho del crucero ${ }^{43}$.

Cerramos con esta referencia nuestro acercamiento al culto de las ánimas benditas del purgatorio en Cádiz, siendo conscientes de que aún queda mucho por investigar y dar a conocer acerca del mismo.

\section{CONCLUSIONES}

Diversas son las hermandades gaditanas nacidas para el auxilio de las ánimas del purgatorio, múltiples también son las representaciones plásticas llegadas hasta nuestros días, así como las referencias a las celebraciones surgidas en torno a esta devoción y toda una serie de escritos que dan buena cuenta de su importancia. Entre todas las congregaciones, destacan las elegidas para nuestro estudio: por un lado, la esclavitud del Santísimo Sacramento y archicofradía de las benditas ánimas y, por otro, la hermandad de San Nicolás de Tolentino localizada en la iglesia del convento de San Agustín. Las interesantes aportaciones documentales así como las obras de arte conservadas en relación con ambas asociaciones revelan la intensidad del fervor con el que fue acogido este culto en Cádiz.

${ }^{43}$ ALONSO DE LA SIERRA FERNÁNDEZ, Lorenzo, op. cit., 2005, p. 93-94. 